November 24, 1900.

PROGRESS OF THE PAN-AMERICAN EXPOSITION BY EDWARD HALE BRUSH.

It is scarcely six months since the real construction work of the Pan-Anerican Exposition was begun, ye wost of the buildings in the main Exposition group stand to-day practically complete, and in a few weeks will be ready for the installation of-exhibits. At the present time the Pan-Aruerican grounds present most interesting scene. The buildings fronting upon the Esplanade and the Court of the Fountains are

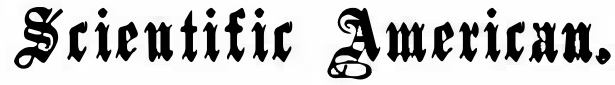

all under roof. Most of them have been covered with do in reaching different parts of the grounds. The staff, and the staff of several has received its coat of permanent buildings in the classic style, the $\$ 400,000$ many colors. The admirable character of the arange- Albright Art Gallery and the New York State buildment of buildings adopted can be very well appreciat- ing, both in white marble, will stand among the trees ed, now that the structures are so far along toward of beautiful Delaware Park, the State and foreign completion. Grouping the principal buildings about buildings will be to the east of the Triumphal Bridge, the two great intersecting courts, each as large as and the Midway buildings will be in the northwest the main court at any previous exposition, secures a portion of the grounds, while opposite, across the splendid effect and ministers also to the comfort of the Plaza, will be the great structure of the Stadium. But visitor, who will have comparatively little walking to about these two main courts will nevertheless be the

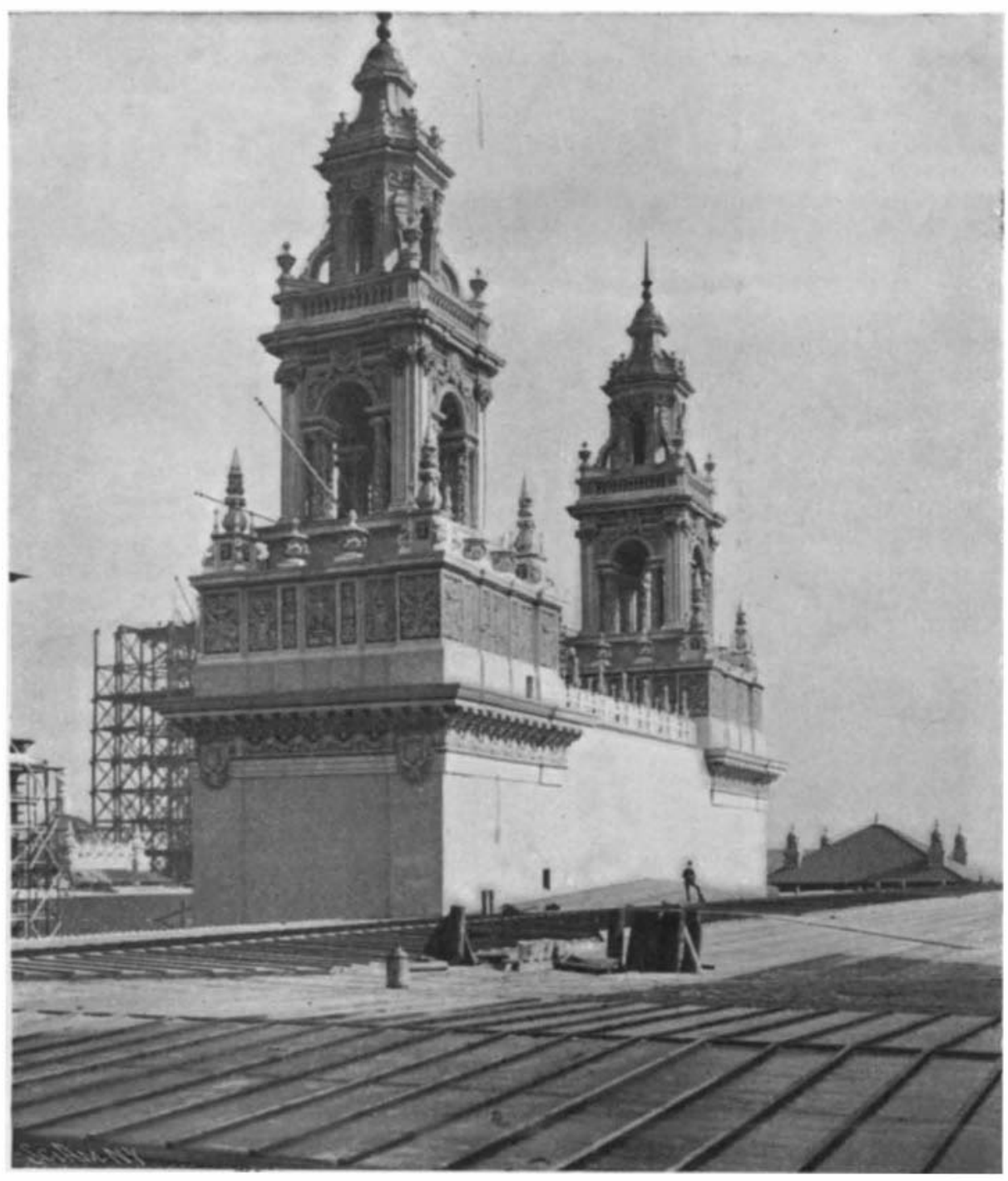

North Towers of Machinery and Transportation Building seen from the Roof.

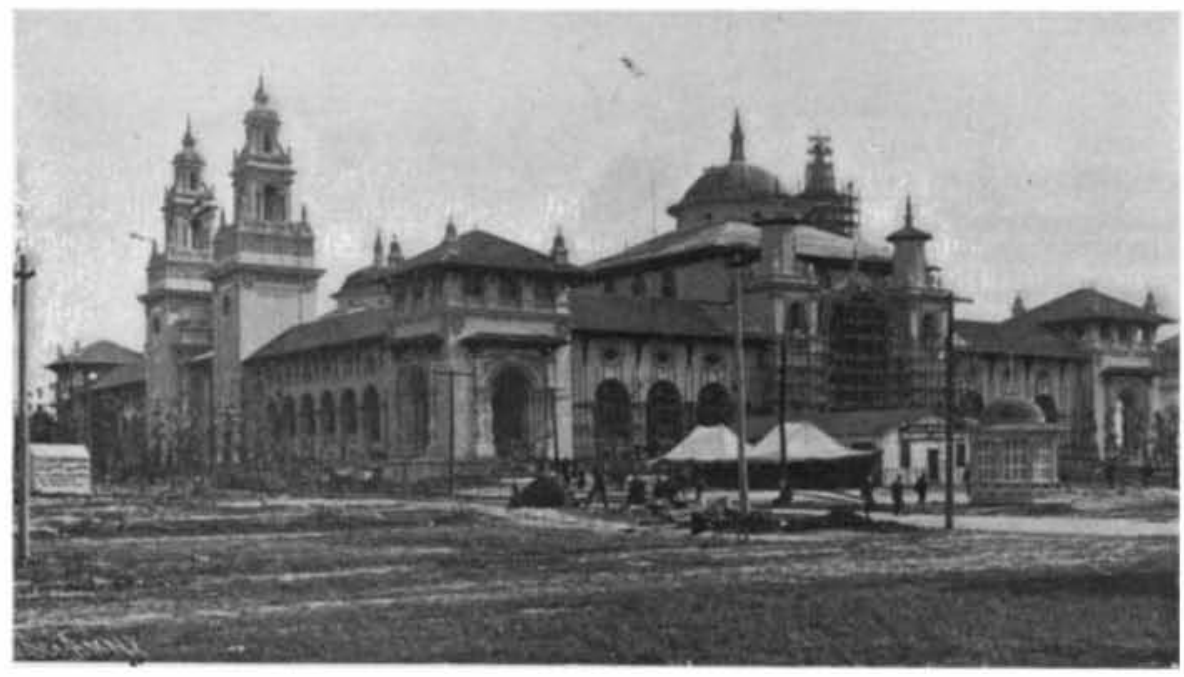

The Machinery and Transportation Building.

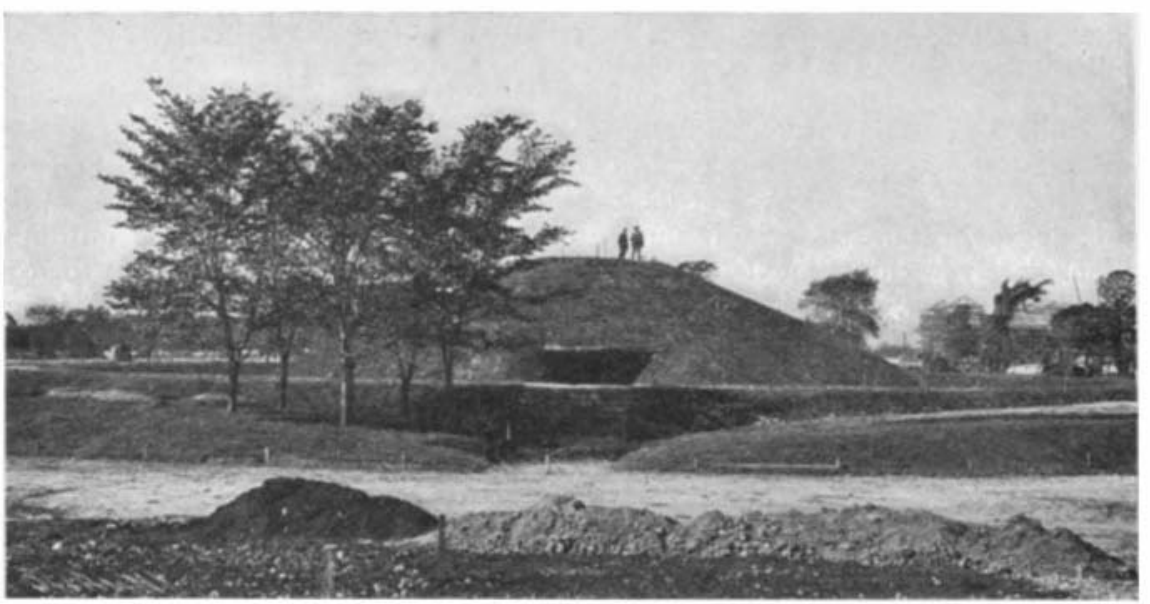

The Burial Mound-A Reproduction of the Work of the Mound-Builders.

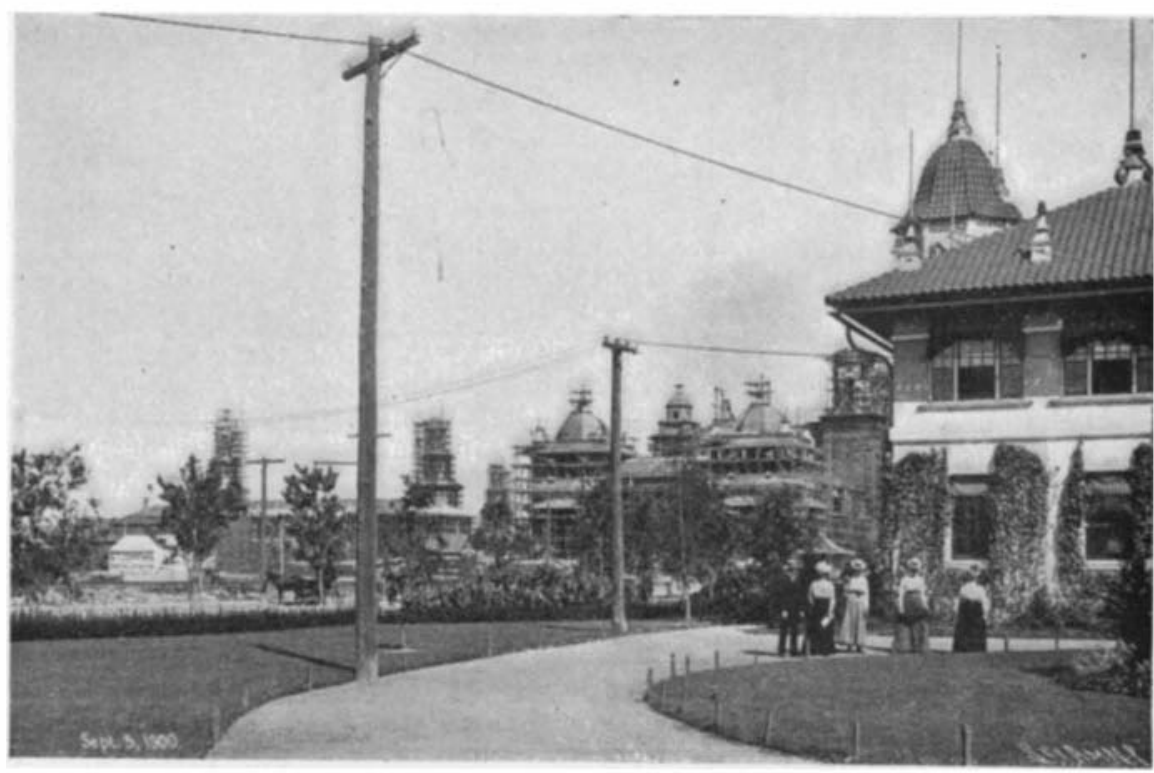

The Exposition Viewed Westward of the Service Building.

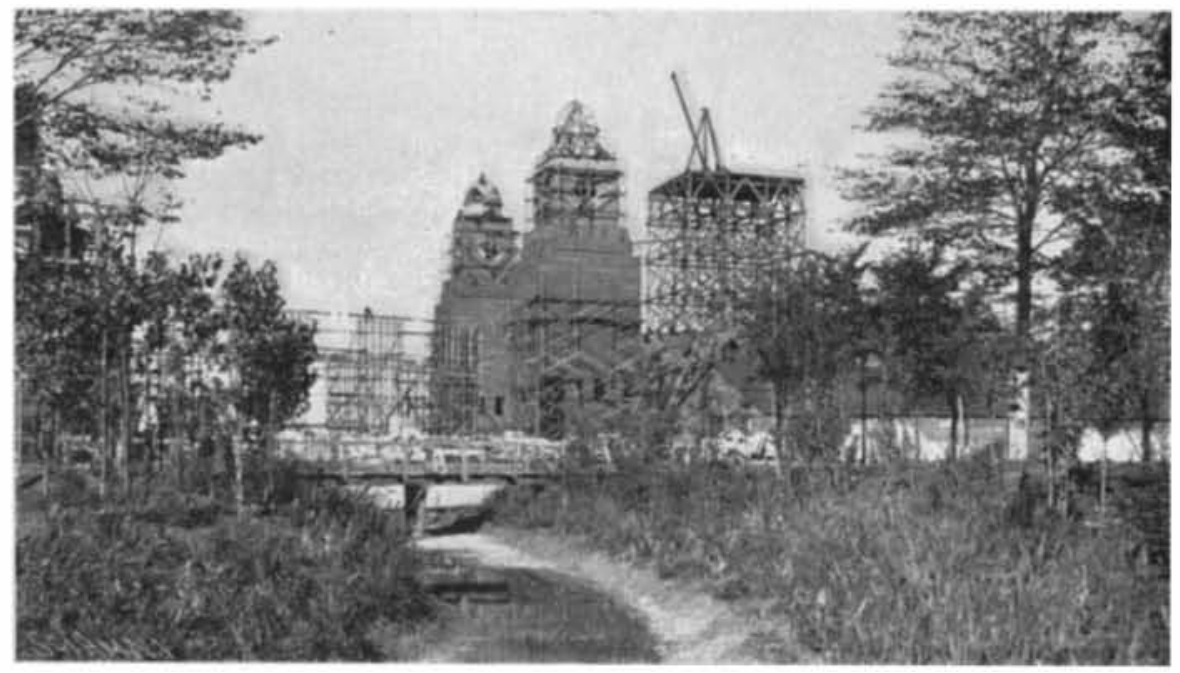

Onited States Government Building from Grove on Mirror Island.

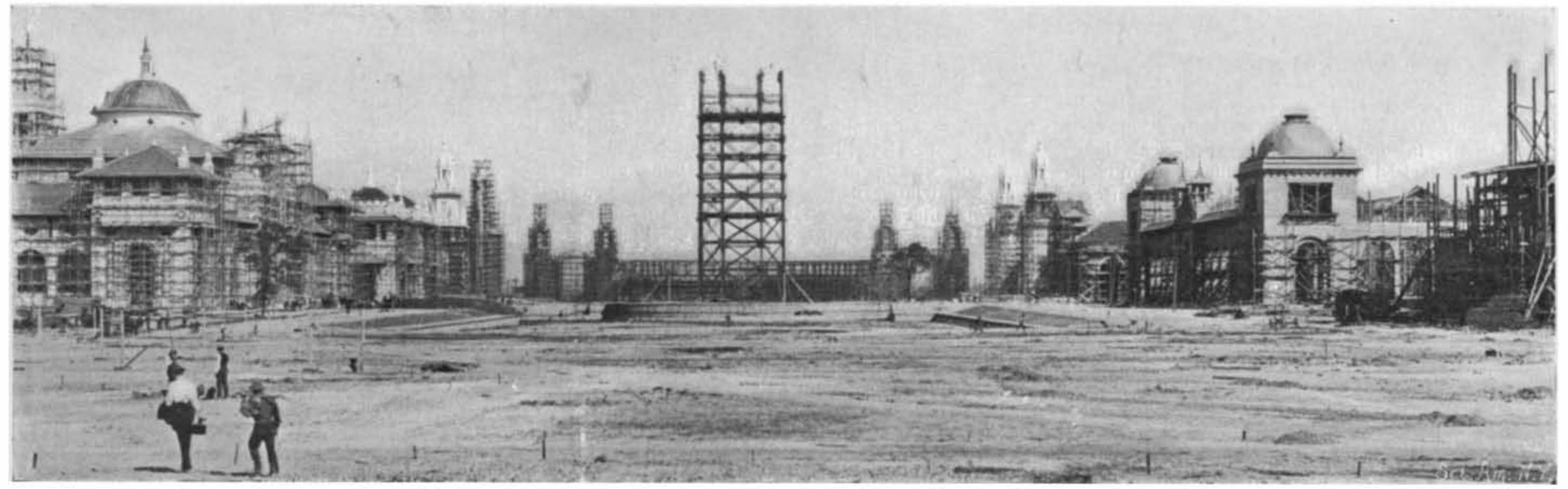

General View of Pan-American Exposition from the Triumphal Bridge.

THE PAN-AMERICAN EXPOSITION AT BUFFALO, NEW YORR. 
great architectural effects of the Exposition. Looking from the Triumphal Bridge, the splendid monumental entrance to this portion of the grounds from the south, one sees looming up at the far end of the vista, at a distance of about one-third of a mile, the Electric Tower which has now reached a height of over 300 feet. Its total height is to be 375 feet. On either side of the buildings of Electricity, Machinery and Transporta tion, Agriculture, Manufactures and Liberal Arts, tion, Agriculture, Manufactures and Liberal Arts,
Ethnology and the Temple of Music. To the right, at one end of the Esplanade, are the three buildings conone end of the Esplanade, are the three buildings con-
stituting the United States government group and connected by colonnades, and to the left are the group for Graphic Arts, Horticulture and Mines, which are connected by conservatories that next sumner will be luxuriant with the rarest and most beautiful plants and flowers. Here then are 13 immense buildings, all immediately within the view, and surrounding these immediately within the view, and surrounding these
two great courts, and all conforming in greater or less two great courts, and all conforming in greater or less
degree to the style of the Spanish Renaissance, which is now seen to be remarkably well adapted to the purposes of the Exposition, combining as it does so many features suitable to the expression of the fantastic ideas and buoyancy of spirit which harmonize with the mood of an Exposition multitude. All of the buildings are to be treated in color instead of left in the monotonous white. These two vast courts around which the buildings are mostly grouped, with the buildings and other architectural features surrounding, gave
a splendid opportunity for embellishment in several respects.

The sculptural adornment of the grounds of the PanAmerican Exposition will be more profuse and elaborate than has ever before been attempted in connection with a similar enterprise. And in saying this I make no exception of either the great World's Fair at Chicago with its Court of Honor or the Paris Exposition with its Alexander Bridge and other highly embellished architectural features. Practically all of the noted sculptors of Pan-America are at work on groups and individual figures which are to adorn and dignify the buildings and grounds of this Exposition. From the Triumphal Bridge on the south, embellished from end to end with symbolic figures and designs, and with its four stately piers, 100 feet in height, carrying mounted standard bearers, to the Electric Tower on the north with its elaborate sculptural scheme terGoddess of Light of terra firma in a figure of the Adams-from one end to the other of this vista, sculp. ture in the most bewildering variety will abound, the charming effect of these forms of beauty being encharming effect of these forms of beauty being enand cascades, and at night by the soft radiance of the electric lights. There will be sculpture expressive of the beneficence of Mother Nature adorning the foun tain at the head of the Court of the Fountains, and at the end of the Esplanade where the horticultural group is situated. At the opposite ends of the Esplanade the sculpture, by such men as R. Hinton Perry and Herbert Adains, will typify man and his institutions. The bert Adains, will typify man and his institutions. The cal representations of the ideas dominant in the sur rounding buildings devoted to machinery and transportation, manufactures and liberal arts, music, eth nology, agriculture and electricity; and the sculpture of the Electric Tower and its beatiful colonnades will portray the ideas associated with the power of the elewents, the mysterious force of electricity, the great wents, the mysterious force of electricity, the great waters amid which Buffalo is situated and which have
wade her so potent an influence in the world of commerce and inc..stry.

There will be some 125 original groups of this sculpture, not including that in the fine arts exhibit in the Albright Art Gallery, and it is engaging the attention of some thirty-tive sculptors, including such exponents of this branch of fine art as George Gray Barnard, Frederic Macmonnies, Daniel C. French, Edwin F.
Elwell, J. Q. A. Ward, F. W. Ruckstuhl, Philip Martiny, E. C. Potter, Herbert Adams, John Gellert, Ralph Goddard, Isidore Konti, and Karl Bitter, the last named sculptor having been chosen to supervise the work of sculptural adornment of the Exposition. His success in carrying out the ambitious allegorical scheme of sculpture devised for the Pan-American, and embodying in the main his own ideas, marks him as a creative genius of high order. Now that so much of the sculptural work is already done and shipped to Buffalo, the magnitude and beauty of this feature of the Exposition is beginning to be realized, and the fact is appreciated that it will mark an era in the progress of this branch of art in Pan-America.

In another respect the arrangement of the main buildings of the Pan-American group, as they have been placed about these courts, lends itself admirably been nlaced about these courts, lends itself admirably
to the purpose of the architects to secure remarkable and fascinating eff ects. It renders possible the greatest and most artistic illumination by means of electric lamps and hydraulic effects ever conceived and carried out by human intellect and inventive genius. This of the Fountains and the Esplanade, will be a feature of the Pan-American Exposition worthy of the fin de siecle enterprise, the stor

The progress made

The progress made by electrical science and the harnessing of Niagara within the last decade, make possible this supreme achievement. With the great Falls plant, which within a short time will be generating over 100,000 horse power, within twenty miles sition by a transmission line, it is fitting that electricity should receive especial prominence at the Exposition, should receive especial prominence at the Exposition, precedents set in this respect. The illuminating area of the courts already described and of the Plaza to the north of the Electric Tower, is three times as large as that at Omaha and two and one-half times as large as that at Chicago, while the character of the buildings, the fantastic outlines many will possess, and their grouping about the courts, will give a peculiar beauty to their penciling in incandescent lights. With the sky lines of the buildings traced in fire against the heavens: with the basin of the Court of the Fountains golden with thousands of floating lights, the cascades resplendent with wysteriously changing fiery hues, mass of shining splendor from the plashing fountain at its feet to the dazzling Goddess of Light upon its topmost pinnacle, - with such a scene to portray, the most skillful word painter will be at a loss where to begin and where to end his task.

The statement that 200,000 electric larups will be used in this illumination conveys some idea of its extent, what it means when such a statement is made grasp is scarcely anything with which such an illumination can be compared, and the visitor must come to see it in order to appreciate the marvelous brilliancy and beauty of the scene which will be created. The incan descent lamps to be used in this illumination will give a peculiar softness and agreeableness to the quality of the light. Are lights will be used to light the interior of the buildings, and rows of these lights will border
the grounds; but the great illumination will be given through the incandescent lamp, which will be introthrough the incandescent lamp, which will be intro-
duced in the fountains and hydraulic features in many novel and startling forms to give a bewitching charac ter to the scene. The electrical experts of the Exposition are now studying on a novel method of turning
the light on and off, so that this operation in itself may the light on and off, so that this operation in itself may
be one of the wonderful features of the electrical dis play.

\section{“The Progress of Invention in the Nineteenth}

Edward W. Byrn, A.M., has done a signal service to the history of invention in writing a dignified and authoritative treatise upon the evolution of the arts the "The Progress of Invention in the Nineteent Century," which has just been issued by the publisher of the SCIENTIFIC AMERICAN. The author is admirably qualified to deal with the subject, having been fo ably qualified to deal with the subject, having been fo a quarter of a century engaged in the examination of
in ventions for patents and having, withal, an ardent interest in all things that make for scientific progress. He has presented a most excellent bird's-eye view of the progress achieved, and he has given in concrete of the century. The author presents his subjects with a pure and rhetorical diction, conveying the though a pure and rhetorical diction, conveying the thought in a terse and lucid way, while still holding true to the
technical nomenclature of the arts. The chapters o this book give a most comprehensive, compact, an coherent account of the progress which distinguishe this as the "golden age " of invention, and which has resulted, especially in the United States, in an unpre ented industrial and commercial deve

Standing on the threshold of the twentieth century, and looking back a hundred years, the nineteenth
century presents in the field of invention a magnificent museum of thoughts crystallized and made immortal, not as passive gems of nature, but as potent, active, useful agencies of man. The period has been a brilby the strongest and best equipped winds. The great works of the ancients are in the main monuments of the manual labor of myriads of workers; not so with modern achievements. The present century has bee practically an age of ideas which find expression in labor-saving inventions, often the product of a singl man. To appreciate what has been done, the cond tions of to-day must be briefly contrasted with those of Byrn has admirably accomplished it in "A Perspective View," a short introduction which forms the first chapter of the book. The second chapter is entitled "Chapter of the book. The second chapter is entitled teenth Century." Each year has listed under it the important discoveries and inventions, together with their authors, which enables the reader to ascertain at a glance the most important inventions and discoveries 1815 Sir Humphry Davy invented the safety lamp; that in 1821 Faraday converted electric current into mechanical motion; that in 1895 Cowles introduced the electrical process of manufacturing aluminium; and that in 1896 Marconi devised his system of wireless telegraphy.

A sample year or two may prove interesting:

1804. Rhodium and Palladium discovered by Wollaston. First Steam Railway and Locomotive, by Richard Trevithick. Col. John Stevens Applies Twin Screw Propellers in Steam Navigation.
Winsor Takes Out British Patent for Illuminating Gas, Lights Lyceum Theater and Organizes First Gas Company. Lucas' Process of Making Malleable Iron Castings.

1893. Acheson's Process for Making Carborundum. The Yerkes Telescope. Edison's Kinetoscope. nace by Willson.

These are a few examples taken at random from a

list which covers a hundred years of invention. This list must not be confounded with the general classification of the subject matter which comprises the principal part of the book. The third chapter is devoted to the Electric Telegraph, and in it will be found a photograph of Prof. Henry's original electro-magnet and a number of other engravings which admirably serve to elucidate the text, including one showing Marconi transmitting the news of the yacht race of 1899 by wireless telegraphy. The next chapter is devoted to the Atlantic Cable, and this is in turn followed by one on the Dynamo and its applications, accompanied by number of excellent engravings.

The Electric Motor, the Electric Light, the Telefollow. and Miscellaneous Applications of Electricity one devoted to the Steam Engine including turbines, another to the Steam Railway, and a third to Steam Navigation. The chapter on Printing gives in the most comprehensive manner the development of the printing press from the time of Benjamin Franklin to the latest octuple press. It also includes the manufacture of paper pulp and the setting of type by the linotype. The chapter on the Typewriter, Sewing-machine and Reaper are fascinating and show that the story of invention is not without its romantic element. In the chapter on Vulcanized Rubber, in which the struggles of Charles Goodyear are described, this is even more pronounced. The chapters on Chemistry, Food and Drink, Medicine, Surgery and Sanitation give a vast amount of information which is not readily accessible. The Bicycle and Automobile are treated at considerable length, and the chapter is well illustrated. The Phonograph, Optics, Photography, X-Rays, all have chapters devoted to thew. Gas-lighting, Civil Engineering, Wood-working, Metal-working, Firearms and Explosives, Textiles, Ice Machines, Liquid Air and minor inventions are all treated in most in. teresting chapters. The book is admirably illustrated and is attractively printed and bound.

\section{Latest News of the Peary Expedition.}

Further details of the Peary expedition have now come to hand. Dr. Leopold Kann was the only mew. ber in that party who arrived on the whaler "Eclipse"
from Davis Strait. Dr. Robert Stein. of the Uuited from Davis Strait. Dr. Robert Stein. of the Uuited
States Geological Survev, decided to wait for transportation which would land him in America, and Mr. Samuel Warmbath of Boston wished to remain at Cape Sabine for a time. Lient. Peary passed the winter at Etah on Swith Sound, near the ispot/ where Dr. Haves had his winter quarters in 1860 , and not far from the scene of the Greely disaster. In February and March Dr. Kann's winter house at Bedford, on Pym Island, was visited three times by members of the Peary expedition; the last time Lieut. Peary himself commanded the sledging party. The Lieutenant stated that about ten months previously he had met Sverdrup in the Kane Basin, north of Sinith Sound. The Sverdrup party had fully explored Eilesmere hinterland, mapping out a region that was hitherto a blank on the charts. When the Peary and Sverdrup parties separated, it was Sverdrup's intention to explore the vast area of land and water in and around Jones Sound beyond Cape Fden. Dr. Kann believes that Sverdrup, on the "Fram." is now wintering in Jones Sound. The autumn has been very tempestuous, and the ice was such as to render navigation next to impossible, and it is not thought that the "Fram" will come home this year. Lieut. Peary had two hundred
dogs and twenty-seven sledges, but underrating the dogs and twenty-seven sledges, but underrating the
difficulties of the journey, and not having a sufficiency of food, most of his dogs died. Dr. Kann considers that it is certain that Lieut. Peary is now wintering at Fort Conger. When Dr. Kann left Cape York on the "Eclipse." on June 9, the "Windward." ex. orders from Lieut. Peary which Dr. Kann had brought orders from Lieut. Peary which
were left with the Esquimaux.

THE Russian government has decided to make the petric system of weights and measures compulsory, and the Minister of Finance is now engaged in considering the time and manner of introducing this reform. 